\title{
EFFECTS OF HONEY PROPOLIS CANDY CONSUMPTION ON MYELOPEROXIDASE ACTIVITY IN UNSTIMULATED SALIVA
}

\section{RATU ANNISA SEPTIANI, NURTAMI SOEDARSONO, SRI ANGKY SOEKANTO*}

\author{
Department of Oral Biology, Faculty of Dentistry, Universitas Indonesia, Jakarta, Indonesia. Email: sasoekanto@gmail.com
}

Received 14 October 2018, Revised and Accepted 12 January 2019

\begin{abstract}
Objective: The objective of this study was to assess the effect of honey propolis candy consumption on myeloperoxidase activity in unstimulated saliva.

Methods: Myeloperoxidase activity was analyzed in saliva using the absorbance value measured with a microplate reader at a wavelength of 450 nm. Measurements were carried out by observing the color change from the oxidation reaction of 3,3-diaminobenzidine and guaiacol.

Results: The honey propolis candy and honey candy groups showed an increase in myeloperoxidase activity after treatment, although the change did
\end{abstract} not reach the level of statistical significance. The mean change in myeloperoxidase activity was not significantly different between the three groups.

Conclusions: Honey propolis candy does not have a strong effect on myeloperoxidase activity.

Keywords: Propolis, Antibacterial, Myeloperoxidase activity.

(C) 2019 The Authors. Published by Innovare Academic Sciences Pvt Ltd. This is an open access article under the CC BY license (http://creativecommons. org/licenses/by/4. 0/) DOI: http://dx.doi.org/10.22159/ijap.2019.v11s1.AR160

\section{INTRODUCTION}

Dental caries are a common oral health concern around the world [1]. According to the results of Basic Health Research (RISKESDAS) 2007, $72.1 \%$ of people in Indonesia experience dental caries [2]. Routine dental examinations and oral hygiene maintenance can help reduce the risk of dental caries. In addition, natural products may benefit oral health and are of interest to researchers and consumers due to their safety and quality [3].

Indonesia has a long history of using medicinal plants (herbs) to treat health issues. The World Health Organization recommends the use of herbs in public health maintenance because they are generally safer than modern medicines [4]. There are various kinds of herbal medicines, and one of them is propolis. Some studies have shown that propolis has the ability to treat various diseases in the oral cavity [5]. Propolis can be used in dentistry for various purposes including the prevention of dental caries [3].

Propolis is a resin produced by Apis mellifera bees from various plant species. Propolis is known to have antibacterial, antioxidant, antifungal, antiviral, anti-inflammatory, antitumor, antiprotozoal, immunomodulator, anesthetic, and radioprotective effects [6,7]. Compounds from three chemical groups have been identified in propolis, namely flavonoids, polyphenols, and terpenoids [6]. The most important ingredient in propolis is flavonoids [3]. Flavonoids can have antibacterial effects by causing damage to the permeability of cell walls, microsomes, and bacterial lysosomes [8].

Saliva is a bodily defense that helps maintain the balance of the oral cavity. Saliva is rather unique in that it is a liquid with antibacterial properties, but it is also a good place for the development of germs and bacteria. Saliva as a whole is a complex liquid composed of major and minor salivary gland secretions, serum from transudation of the gingival gap, and components such as oral microorganisms, leukocytes, and epithelial cells [9]. Saliva is 94-95\% water, and the rest is inorganic and organic materials. The inorganic components of saliva include $\mathrm{Na}+, \mathrm{K}+, \mathrm{Ca}^{2+}, \mathrm{Mg}^{2+}$, chlorine ions $\left(\mathrm{Cl}^{-}\right), \mathrm{HCO}_{3}^{-}$, and phosphate, whereas the organic components include protein, fatty acids, lipids, glucose, amino acids, urea, and ammonia. Protein in saliva consists of immunoglobulin and non-immunoglobulin proteins. One of the salivary non-immunoglobulin proteins that act as an antibacterial agent to maintain balance in the oral cavity is peroxidase [10].

This peroxidase system consists of lactoperoxidase and myeloperoxidase, which are enzymes that form the body's defense system against microorganisms [10]. This is proven in patients with periodontal disease will be positively correlated with myeloperoxidase activity [11]. Salivary myeloperoxidase is derived from leukocytes secreted into the oral cavity through crevicular fluid. This enzyme serves as a catalyst for the formation of hypochlorite ions $\left(\mathrm{OCl}^{-}\right)$, which are antibacterial. The formation of $\mathrm{OCL}^{-}$ions is influenced by the reaction of $\mathrm{Cl}^{-}$and hydrogen peroxide $\left(\mathrm{H}_{2} \mathrm{O}_{2}\right)$ in the oral cavity $[9,12]$.

The mechanism of myeloperoxidase activity in saliva is affected by the quantity of $\mathrm{H}_{2} \mathrm{O}_{2}$ produced by oral bacteria: Its activity may increase when $\mathrm{H}_{2} \mathrm{O}_{2}$ produced by oral bacteria increases and decrease when $\mathrm{H}_{2} \mathrm{O}_{2}$ produced by oral bacteria decreases [13]. Therefore, the use of an antibacterial agent such as propolis may affect myeloperoxidase activity of saliva due to the reduced amount of $\mathrm{H}_{2} \mathrm{O}_{2}$-producing bacteria. If there is a significant change, myeloperoxidase activity will not be able to maintain the balance of oral bacteria, causing bacteria to grow uncontrollably.

The previous research has examined dosages of propolis derived from toothpaste, mouthwash, and candy [14]. The candy form is practical, easy to consume and has an acceptable taste. There is an X candy containing propolis sold on the market. At present, the University of Indonesia is developing honey propolis candy containing $5 \%$ propolis and $3 \%$ honey [15]. This candy has been proven by in vivo tests to reduce the prevalence of Streptococcus mutans bacteria in saliva samples from caries and caries-free subjects.

In addition to developing honey propolis candy, the University of Indonesia has also developed honey candy without propolis. This candy has a composition similar to honey propolis candy, but it does 
not contain propolis. The honey candy has also been proven by in vivo tests to decrease the prevalence of $S$. mutans bacteria in saliva samples from caries and caries-free subjects.

The previous studies have proved that flavonoids in propolis can decrease myeloperoxidase activity in the leukocytes of patients with atherosclerosis [16]. However, there has been no research on the antibacterial effectiveness of honey propolis candy on myeloperoxidase activity in saliva. Therefore, this study aimed to examine the effect of the consumption of honey propolis candy on myeloperoxidase activity in unstimulated saliva.

\section{METHODS}

This experimental research was conducted from July to November 2014 at the Oral Biology Laboratory of Faculty of Dentistry, Universitas Indonesia. The subjects were 120 students in the Faculty of Dentistry, Universitas Indonesia (FKG UI), who fulfilled the inclusion criteria. The inclusion criteria were students from Faculty of Dentistry, Universitas Indonesia, aged 19-23 years with good general health, good oral health, non-smokers, no alcohol consumption, no periodontal abnormalities, and willing to provide informed consent. Exclusion criteria were current orthodontic treatment, systemic diseases that manifest in the oral cavity, and the use of drugs or actions that affect oral conditions.

The independent variables of this study were honey propolis candy, honey candy, and X propolis candy use, whereas the dependent variable was myeloperoxidase activity in unstimulated saliva. The tools and materials used in this study included a mouth mirror, flashlight, probes, microplate reader (Benchmark), microwell, centrifuge, $-80^{\circ} \mathrm{C}$ freezer, portable freezers, microcentrifuge tubes of 15 and $1.5 \mathrm{~mL}$, Eppendorf pipette, 3.47 mM DAB (3,3-diaminobenzidine)+176 mM guaiacol, $4 \mathrm{mM}$ $\mathrm{H}_{2} \mathrm{O}_{2}$ in $0.3 \mathrm{M}$ Tris- $\mathrm{HCl}$ buffer ( $\mathrm{pH} 7.5$ ), $100 \mathrm{~mm}$ dapsone, and $0.5 \mathrm{~N} \mathrm{HCl}$.

After screening and informed consent procedures, the participants were divided into three groups: 40 subjects consumed honey propolis candy, 40 subjects consumed honey candy, and 40 subjects consumed $\mathrm{X}$ propolis candy. Each candy was consumed twice daily for 7 days in a row.

The first saliva sample was collected before candy consumption. Participants were instructed not to brush their teeth, not to use mouthwash, not to eat, and not to drink (except mineral water) for at least 1.5 h. Participants were instructed to sit relaxed and collect the unstimulated saliva $\pm 5 \mathrm{~mL}$ into a $15 \mathrm{~mL}$ microcentrifuge tube. After 7 days of candy consumption, the second saliva sample was collected in the same manner. Saliva samples were stored in a portable freezer until testing was performed at the Oral Biology Laboratory of FKG UI. If the sample was not immediately used, it was frozen at $-80^{\circ} \mathrm{C}$ to inhibit enzyme until use. Freeze-thaw cycles were avoided.
After the collection was complete, the saliva samples were centrifuged at $10,000 \mathrm{rpm}$ at $4^{\circ} \mathrm{C}$ for $10 \mathrm{~min}$. Supernatant saliva was separated from the pellet, and $100 \mu \mathrm{L}$ supernatant was input into a microwell using an Eppendorf pipette. The following reagents were then added: $176 \mathrm{mM}$ guaiacol, $3.47 \mathrm{mM} \mathrm{DAB}, 4 \mathrm{mM} \mathrm{H}_{2} \mathrm{O}_{2}$ and $1 \mathrm{mM}$ dapsone dissolved in $0.3 \mathrm{M}$ Tris- $\mathrm{HCl}$ buffer $(\mathrm{pH}=7.5)$. The reagents and saliva samples were incubated for $30 \mathrm{~min}$. After incubation, oxidation occurred and caused the color to change to brownish-yellow. The microwell was immediately inserted into a calibrated microplate reader and read at a wavelength of $450 \mathrm{~nm}$. The absorbance values were calculated using a program on the microplate reader. Myeloperoxidase activity is seen from guaiacol and DAB oxidation, and dapsone addition is an inhibitor of lactoperoxidase activity [12].

Statistical analyses were performed using SPSS 17 software. Before analysis, a normality test was performed. The Shapiro-Wilk test was used because the sample size was $<50$. The data distribution was not normal, so the Wilcoxon test was used to evaluate the changes in myeloperoxidase activity before and after treatment. The KruskalWallis test was used to assess changes in myeloperoxidase activity between the three treatment groups.

\section{RESULTS}

The purpose of this study was to determine the effect of honey propolis candy consumption on myeloperoxidase activity in unstimulated saliva in three groups, namely honey propolis candy (Group A), honey candy (Group B), and X propolis candy (Group C).

As shown in Fig. 1, Group A showed an absorbance value before the treatment of 0.09263 and an absorbance value after the treatment of 0.10270 , resulting in an increase of 0.01005 . Group B showed an absorbance value before the treatment of 0.09030 and an absorbance value after the treatment of 0.09980 , resulting in an increase of 0.00931 . Group C showed an absorbance value before the treatment of 0.08688 and an absorbance value after the treatment of 0.08460 , resulting in a decrease of 0.00229 . Although none of these changes were statistically significant (Table 1, all p $>0.05$ ), Groups A and B did show a trend of increased activity after treatment $(\mathrm{p}<0.10)$. The mean changes between the three groups were not statistically significant (Table 2).

\section{DISCUSSION}

The purpose of this study was to determine the effect of honey propolis candy consumption on myeloperoxidase activity in unstimulated saliva. Yi-Chih Tsai et al. previously showed that propolis has an antibacterial effect by damaging the DNA of bacteria [17]. De Luca et al. proved that propolis extract inhibits the growth of S. mutans, Streptococcus sanguinis, Streptococcus salivarius, and Lactobacillus casei bacteria [5].

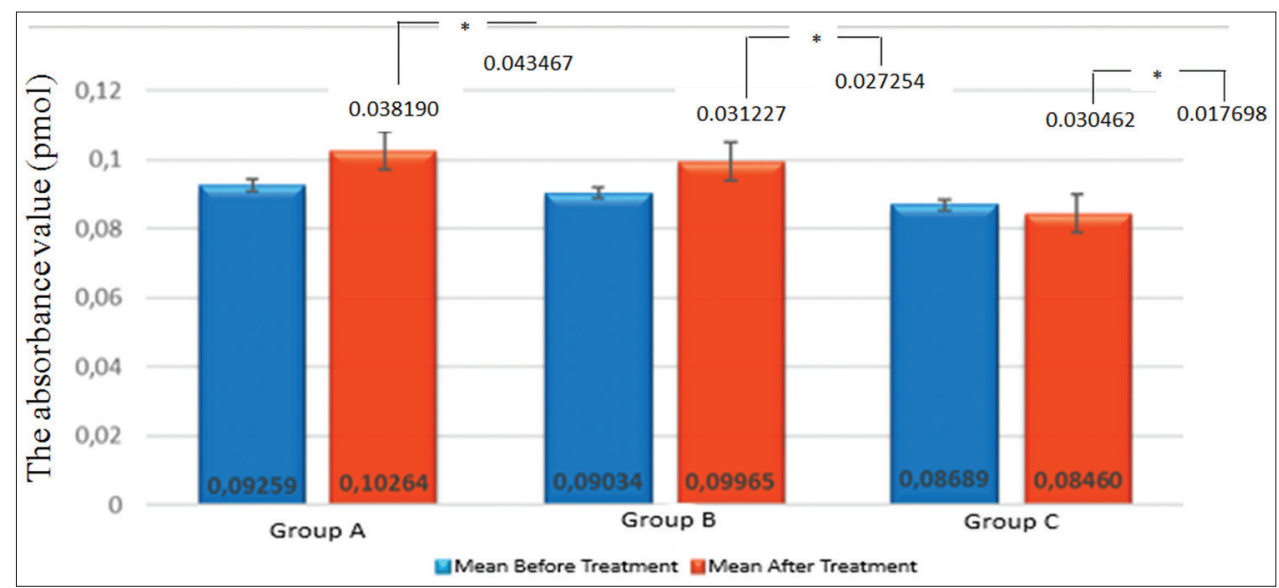

Fig. 1: Mean myeloperoxidase activity between groups 
Table 1: Myeloperoxidase activity before and after treatment for each

\begin{tabular}{llll}
\hline Group & Before treatment & After treatment & Wilcoxon (Sig.) \\
\hline Group A $(\mathrm{n}=40)$ Mean \pm SD & $0.09263 \pm 0.038190$ & $0.10270 \pm 0.043467$ & 0.077 \\
Group B $(\mathrm{n}=40)$ Mean \pm SD & $0.09030 \pm 0.031227$ & $0.09980 \pm 0.027254$ & 0.053 \\
Group C $(\mathrm{n}=40)$ Mean \pm SD & $0.08688 \pm 0.030462$ & $0.08460 \pm 0.017698$ & 0.684 \\
\hline
\end{tabular}

${ }^{*} \mathrm{p}>0.05$

Table 2: Mean change in myeloperoxidase activity before and after treatment

\begin{tabular}{ll}
\hline Group & $\begin{array}{l}\text { Mean value of the activity changes } \\
\text { before and after treatment }\end{array}$ \\
\hline Group A $(\mathrm{n}=40)$ Mean \pm SD & $0.01008 \pm 0.040794$ \\
Group B $(\mathrm{n}=40)$ Mean \pm SD & $0.00933 \pm 0.029710$ \\
Group C $(\mathrm{n}=40)$ Mean \pm SD & $0.00227 \pm 0.030769$ \\
Kruskal-Wallis (Sig.) & 0.424 \\
\hline${ }^{*} p>0.05$ &
\end{tabular}

This study showed a slight increase in myeloperoxidase activity in the groups treated with honey propolis candy and honey candy, although it was not statistically significant. Honey propolis candy resulted in a higher increase in myeloperoxidase activity than honey candy, but again, the difference was not statistically significant. This result was not in line with the previous studies that proved honey propolis candy and honey candy have antibacterial effects by reducing the prevalence of $S$. mutans bacteria. The increase in myeloperoxidase activity in Groups A and B may have been caused by the glucose and sugar content in honey propolis candy and honey candy. Glucose can cause bacteria in the oral cavity to grow more, and the $\mathrm{H}_{2} \mathrm{O}_{2}$ produced by the bacteria could increase and cause an increase in myeloperoxidase activity. In addition, the honey content in both candies can produce $\mathrm{H}_{2} \mathrm{O}_{2}$ through glucose oxidase enzyme activity $[18,19]$.

The greater increase in Group A may have been caused by the flavonoid content in propolis, which could produce $\mathrm{H}_{2} \mathrm{O}_{2}$ as an inducer of DNA damage to bacteria. Flavonoids from propolis act as temporary carriers of electrons received from transition metal ions $\left(\mathrm{Fe}^{2+} \rightarrow \mathrm{Fe}^{3+}\right)$, which are passed to oxygen molecules and react to form superoxide $\left(\mathrm{O}_{2} \rightarrow \mathrm{O}_{2}^{-}\right)$. Superoxide $\left(\mathrm{O}_{2}^{-}\right)$can react with hydrogen $\left(\mathrm{H}^{+}\right)$to produce $\mathrm{H}_{2} \mathrm{O}_{2}[17]$. If there is an increase in $\mathrm{H}_{2} \mathrm{O}_{2}$ concentration, then myeloperoxidase activity also increases. $\mathrm{H}_{2} \mathrm{O}_{2}$ in saliva is considered to improve the defense system in the oral cavity by increasing the substrate for myeloperoxidase activity.

$\mathrm{X}$ propolis candy is thought to prevent the growth of oral bacteria [20]. This was seen in the decrease in myeloperoxidase activity in Group C, although it was not statistically significant. Unlike the honey candy, X propolis candy contains polydextrose, and a low-calorie and watersoluble food sweetener. This sweetener produces $20 \%$ less lactic acid than glucose. Another advantage of this sweetener is that it inhibits acid production, cell aggregation, and plaque formation by S. mutans [20]. Thus, polydextrose in this candy was not expected to increase the production of $\mathrm{H}_{2} \mathrm{O}_{2}$ by bacteria.

This study is subjected to several limitations. First, we were not able to rule out all other variables that may have affected myeloperoxidase activity in the saliva samples from our participants. For example, the presence of $\mathrm{H}_{2} \mathrm{O}_{2}$, hormonal changes such as menstruation, and various saliva circumstances could affect myeloperoxidase activity in saliva samples.

There has been considerable discussion about finding alternate medications to fight caries. Recently, several studies showed promising alternative proposal combination as anticariogenic agents [21, 22].
However, further studies should be performed in order to investigate other properties of propolis tofight caries.

\section{CONCLUSIONS}

Our study found no significant difference in myeloperoxidase activity related to honey propolis candy consumption. This suggests that honey propolis candy does interfere with the effects of saliva on creating balance in the oral cavity.

\section{CONFLICTS OF INTEREST}

The authors report no conflicts of interest.

\section{REFERENCES}

1. Ngunyen NV. Dental caries situation of secondary school student in Huongtra district Thua Thien Hue Province. J Sci 2010;61:144-51.

2. Ministry of Health, Republic of Indonesia. Basic of health Research 2007. Jakarta: Ministry of Health, Republic of Indonesia; 2008.

3. Skaba D, Morawiec T, Tanasiewicz M, Mertas A, Bobela E, Szliszka E, et al. Influence of the toothpaste with Brazilian ethanol extract propolis on the oral cavity health. Evid Based Complement Alternat Med 2013;2013:215391.

4. Sari LO. Traditional medicine usage with considering the advantage and safety. 2006; $3: 1-7$.

5. De Luca MP, Franca JR, Macedo FA, Grenho L, Cortes ME, Faraco AA, et al. Propolis varnish: Antimicrobial properties against cariogenic bacteria, cytotoxicity, and sustained-release profile. Biomed Res Int 2014;2014:348647.

6. Koo H, Rosalen PL, Cury JA, Park YK, Bowen WH. Effects of compounds found in propolis on Streptococcus mutans growth and on glucosyltransferase activity. Antimicrob Agents Chemother 2002;46:1302-9.

7. Sánchez N, Miranda S, Vit P, Rodríguez-Malaver AJ. Propolis protects against oxidative stress in human saliva. J ApiProd Apimed Sci 2010;2:72-6

8. Di CG, Mascolo N, Angelo A, Capasso F. Minireview flavonoids : Old and new aspects of a class of natural therapeutic drugs. Life Sci 1999;65:337-53.

9. Boufadi YM, Soubhye J, Riazi A, Rousseau A. Characterization and antioxidant properties of six Algerian propolis extracts : Ethyl acetate extracts inhibit myeloperoxidase activity. Int $\mathrm{J}$ Mol Sci 2014; $15: 2327-45$.

10. Amerongen VNA. Saliva and Salivary Glands. Yogyakarta: Gadjah Mada University Press; 1991. p. 1-2, 18-20, 37-38.

11. Tenovuo J, Mäkinen KK, Sievers G. Antibacterial effect of lactoperoxidase and myeloperoxidase against bacillus cereus. Antimicrob Agents Chemother 1985;27:96-101.

12. Sakamoto W, Fujii Y, Kanehira T, Asano K, Izumi H. A novel assay system for myeloperoxidase activity in whole saliva. Clin Biochem 2008;41:584-90

13. Vučićević-Boras V, Topić B, Cekić-Arambašin A, StavljenićRukavina A, Zadro R, Devčić T. Measurement of salivary peroxidase values in unstimulated and stimulated whole saliva in a dental student population. Acta Stomat Croat 2001;2001:357-9.

14. Guentsch A, Preshaw PM, Bremer-Streck S, Klinger G, Glockmann E, Sigusch BW, et al. Lipid peroxidation and antioxidant activity in saliva of periodontitis patients: Effect of smoking and periodontal treatment. Clin Oral Investig 2008;12:345-52.

15. Sahlan M R. Hard Candy Propolis for Oral Health in Jakarta. Jakarta: Universitas Indonesia; 2011. p. 1-5.

16. Morawiec T, Dziedzic A, Niedzielska I, Mertas A, Tanasiewicz M, Skaba D, et al. The biological activity of propolis-containing toothpaste on oral health environment in patients who underwent implant- 
supported prosthodontic rehabilitation. Evid Based Complement Alternat Med 2013;2013:704947.

17. Farooqui T, Farooqui AA. Oxidative stress in vetebrates and invetebrates: Moleculear aspect of signalling. $1^{\text {st }}$ ed. North America: Wiley-Blackwell; 2014. p. 245-53.

18. Kaczmarek U. Peroksidase activity in saliva: Origin and functions. Nat Inst Health 2013;19:405-11.

19. Thomas EL, Jefferson MM, Cook GS, King CC. Leukocyte myeloperoxisidase and salivary lactoperoxidase: Identification and quantification in human mixed saliva. J Dental Res 1994;4:73.
20. Setsu E. Cariogenicity of polydextrose and refined polydextrose as a substrate. J Sci 1989;15:1-11

21. Soekanto SA, Rosithahakiki N, Suniarti DF, Sahlan M. Comparison of The Potency of Several Fluoride-Based Varnishes as an Anticariogenic on Calcium, Phosphate, and Fluoride Ion Levels. Int J App Pharm. 9:55-9.

22. Soekanto SA, Fadillah F, Nuraisiya P, Gultom F, Sarwono AT. The Potential of Several Fluoride-Based Varnishes As Remineralization Agents: Morphological Studies, Dentin Surface Hardness, and Crystallinity Tests. Int J App Pharm, 2017;2:60-6. 